\title{
A PERÍCIA CONTÁBIL E AS EXIGÊNCIAS DO NOVO CÓDIGO DE PROCESSO CIVIL: A PERCEPÇÃO DOS PERITOS E ACADÊMICOS E SOB A ÓTICA DO DISCURSO DO SUJEITO COLETIVO
}

\author{
Nome \\ UDO Strassburg \\ Instituição/Afiliação Univerdade Estadual do Oeste do Paraná - UNIOESTE \\ País \\ Resumo da \\ Biografia \\ Graduação em Ciências Contábeis, especialização em Controladoria e Gerência \\ Financeira, MBA em Perícia Contábil, Mestrado em Controladoria e Contabilidade \\ Estratégica, Doutorado em Desenvolvimento Regional e Agronegócio. Professor \\ da UNIOESTE / Cascavel PR desde 1995. \\ Contato principal para correspondência.

$\begin{array}{ll}\text { Nome } & \text { Niqueli Ortolan } \\ \text { Instituição/Afiliação } & \text { Universidade Estadual do Oeste do Paraná - UNIOESTE } \\ \text { País } & \text { Brasil } \\ \text { Resumo da } & \text { Bacharel em Ciências Contábeis e em Secretariado Executivo da UNIOESTE, MBA } \\ \text { Biografia } & \text { Executivo em Estratégicas Empresariais - Univel }\end{array}$ \\ Nome Luanda Borsoi \\ Instituição/Afiliação Universidade Estadual do Oeste do Paraná - UNIOESTE \\ País \\ Resumo da \\ Biografia \\ Bacharel em Curso de Ciências Contábeis pela UNIOESTE
}

RESUMO: O presente estudo teve o objetivo de analisar as consequências que as exigências do novo Código de Processo Civil trouxeram para a Perícia Contábil. Foi utilizada uma pesquisa descritiva e levantamento, delineada como análise do discurso do sujeito coletivo, com abordagem qualitativa e quantitativa. $\mathrm{O}$ estudo foi aplicado a 10 peritos contadores e 24 alunos concluintes do Curso de Ciências Contábeis. Em relação aos resultados encontrados, verificouse que os peritos destacaram diversos pontos, enfatizando as consequências oriundas das mudanças do NCPC, sendo a maioria favorável, com ênfase em pontos positivos. Já, para os concluintes do curso de Ciências Contábeis também destacaram diversas consequências de sua aplicação, mas a ênfase foi no sentido de que a nova lei dificulta a sua entrada, como perito e demandará bem mais esforço para a sua manutenção. De uma forma geral notou-se que os peritos visualizaram estas mudanças como algo benéfico para a profissão, tendo profissionais qualificados, especialistas. Os estudantes (concluintes) focaram nas exigências impostas pelo NCPC. Desta forma verificou-se que as contribuições foram no sentido de explicitar a visão de cada uma das partes envolvidas na pesquisa, cada um visualizando aquilo que é melhor para si, sem deixar de destacar aqueles pontos que são benéficos para o todos, peritos, estudantes, justiça, população, etc.

PALAVRAS-CHAVE: Perícia Contábil. Novo Código de Processo Cível. Análise do Discurso do Sujeito Coletivo.

\section{INTRODUÇÃO}

A Contabilidade possui várias áreas de atuação, conforme exposto na Resolução do 


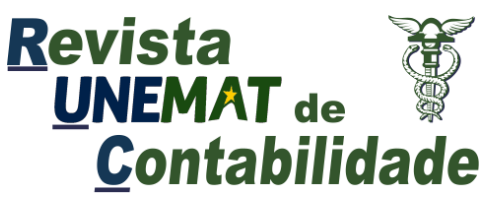

v. 8, n. 16,2019

Conselho Federal de Contabilidade (CFC) nº 898/2001, o contador está apto para exercer as seguintes funções: analista, assessor, assistente, auditor, consultor de tributos, controlador de arrecadação, controller, escritor, escriturador contábil ou fiscal, fiscal de tributos, legislador, organizador, perito, pesquisador, planejador, professor, redator, revisor. (CFC, 1983).

No meio jurídico, a principal função exercida pelo profissional contábil é a de perito, que deve resolver problemas contábeis relacionados à legislação ou questões específicas das áreas cível, trabalhista e de crimes contra o patrimônio (ministério público, varas da família, etc.). Isso é possível através da realização da perícia contábil que visa a elaboração do laudo pericial contábil.

Além de possuir as aptidões da profissão, o perito deve observar as mudanças ocorridas na área jurídica como no Código de Processo Civil, que será tratado neste estudo e se aplicam também ao profissional perito nas seguintes condições: na seção II (145 a 147) do perito e na seção VII (421 a 437) da prova pericial. Para Donizetti (2015), um sistema processual civil, que não proporcione à sociedade o reconhecimento e a realização dos direitos, ameaçados ou violados, que têm cada um dos jurisdicionados, não se harmoniza com as garantias constitucionais de um Estado Democrático de Direito.

Recentemente, o novo Código de Processo Civil (CPC) de 2015, vem reafirmar a importância e o reconhecimento do perito que no exercício de sua profissão está qualificado para fazer o laudo pericial que é indispensável para a correta tomada de decisão dos juízes. Já, que há casos em que os magistrados não têm conhecimento técnico, necessitando desta maneira do trabalho elaborado pelo perito. (DONIZETTI, 2015).

No Código de Processo Civil de 1973, os magistrados tinham mais liberdade para fazer a nomeação do perito, já que os peritos eram escolhidos entre os profissionais legalmente habilitados e que mantinham vínculo com o juiz e com o cartório ao qual ele pertence. No entanto, com o atual CPC de 2015 as exigências para a escolha dos peritos aumentaram, já que serão nomeados os profissionais de nível universitário, devidamente inscritos no órgão de classe competente e que mantenham atualizado o seu cadastro junto ao Tribunal de Justiça do estado de atuação, conforme os artigos 156 a 158 do novo CPC (2015), além das novas exigências como a especialidade no objeto da perícia. Diante disso, o profissional contábil que deseja atuar na área de perícia deve atender as exigências do novo CPC e do Conselho Federal de Contabilidade. (DONIZETTI, 2015).

Nesse contexto, o presente estudo se justifica por se tratar de uma norma legal nova e que vem introduzir alterações em algo que foi concebido a 42 anos atrás (1973), e que é desconhecido de muitos. Também porque a atuação do perito deve ser pautada neste código, cumprindo com todos os seus requisitos. Outra justificativa está centrada na necessidade de investigar quais são as consequências que as exigências do novo Código de Processo Civil trarão para a Perícia Contábil. Com estas justificativas, este estudo tem como problema de pesquisa responder a seguinte questão: quais são as consequências que as exigências do novo Código de Processo Civil trouxeram para aqueles que atuam e que irão atuar com a Perícia Contábil, na opinião dos estudantes de Ciências Contábeis e peritos contadores que atuam na comarca de Cascavel.

O trabalho foi realizado no período de março de 2017 a outubro de 2017 no município de Cascavel/Paraná com os alunos concluintes dos cursos de Ciências Contábeis, e com peritos contábeis que atuam na comarca de Cascavel, como o intuito de realizar um contraponto entre as opiniões de quem já atua no mercado e quem poderá vir a atuar, visto que as exigências atingem ambas as partes. O referido estudo teve como alvo verificar quais as consequências das exigências do novo Código de Processo Civil para os peritos e para aqueles que podem se tornar peritos contadores em um futuro próximo.

Para alcançar os objetivos deste trabalho foi utilizado levantamento ou survey, pesquisa 


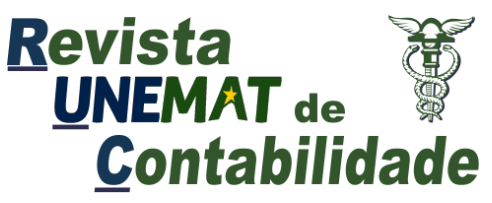

v. 8, n. 16,2019

descritiva, o método utilizado foi o discurso do sujeito coletivo (DSC) e pesquisa com abordagem qualiquantitativa. O Discurso do Sujeito Coletivo - DSC, segundo Lefèvre e Lefèvre (2012, p. 23), "consiste em um conjunto de instrumentos destinados a recuperar e dar a luz às Representações Sociais - RS, mormente as que aparecem sob a forma verbal de textos escritos e falados, apresentando tais representações sob a forma de painéis de depoimentos coletivos".

Ao refletirem como se realiza uma pesquisa com DSC Lefèvre e Lefèvre (2005 e 2012) dizem que o DSC é um técnica de pesquisa qualitativa criada para fazer uma coletividade falar, como se fosse um só indivíduo. Ela constitui uma nova ferramenta para a pesquisa qualitativa e representa uma transformação na qualidade, na eficiência e no alcance das pesquisas qualitativas.

Para produzir o DSC, são necessárias três etapas, assim definidas por Lefèvre e Lefèvre (2005): 1) Expressões Chave (Ech), que são trechos selecionados do material verbal, que melhor descrevem seu conteúdo; 2) Ideias Centrais (Ics), também chamadas de categoias, são fórmulas sintéticas que melhor descrevem os sentidos do material verbal coletado e também nos conjuntos de respostas de sentido semelhante ou complementar; 3) Ancoragens (Acs), que são fórmulas sintéticas que descrevem não mais os sentidos, mas as ideologias, os valores, as crenças presentes no material verbal das respostas individuais ou nas agrupadas sob a forma de afirmações genéricas destinadas a enquadrar situações particulares.

Desta forma, esta pesquisa se caracterizou como um estudo compreensivista, onde foram tomados como base os pontos de vista dos sujeitos participantes (peritos contadores atuantes na comarca de Cascavel e concluintes do curso de Ciências Contábeis, que já cursaram a disciplina de Perícia Contábil), buscando identificar a representação social que existe no contexto das mudanças ocorridas com a entrada em vigor do Novo Código de Processo Civil. Para auxiliar na análise dos dados coletados com as questões abertas foi utilizado o software denominado de Qualiquantisoft, que é um método de análise para pesquisa de opinião. Segundo Lefevre e Lefevre (2012, p. 16), o software Qualiquantisoft ${ }^{\circledR}$ foi desenvolvido para auxiliar "pesquisas de opinião, de representação social. Com isso, para a realização desse estudo foram necessários dados, e informações coletadas que são discriminadas conforme segue nos tópicos a seguir. A coleta de dados foi realizada através da utilização de questionário estruturado com 8 questões fechadas e 9 abertas que foram aplicados aos alunos concluintes de Ciências Contábeis da Universidade Estadual do Oeste do Paraná (UNIOESTE), que já haviam cursado a disciplina de Perícia Contábil e também a profissionais que atuam como peritos contadores e que atuam na comarca de Cascavel,Paraná.

Como contribuição do presente trabalho busco-se destacar os pontos alterados que trouxeram maior significância para a profissão contábil, destacando como era antes e como deve ser agora. Outra contribuição está no sentido de desvendar a opinião dos peritos e de provávei futuros peritos sobre as consequências que estas alterações estariam trazendo para a vida deles.

O estudo foi organizado e distribuído em quatro capítulos: introdução, , estudos anteriores, fundamentação teórica, a descrição e análise de dados e as conclusões. Assim, no primeiro capítulo onde foi realizada a introdução e apresentada a contextualização e justificativa, descrição do problema, objetivo, metodologia, delimitação e estrutura do trabalho. No segundo capítulo, abordou-se os estudos anteriores.No terceiro capítulo foi realizada a fundamentação teórica. E no quarto capítulo ocorreu a descrição e análise dos dados do trabalho através das pesquisas e entrevistas realizadas com alunos concluintes dos cursos de Ciências Contábeis e profissionais peritos contadores que atuam na comarca de Cascavel. Por fim, as conclusões decorrentes dos procedimentos de análise de pesquisa. 


\section{Estudos Anteriores}

Sobre perícia contábil já se tem poucas publicações a serem consultadas e especificamente sobre o Novo Código de Processo Civil - NCPC, relacionado a área contábil foi encontrado menos ainda. Foram relizadas buscas nas bases de dados do SPELL, Periódicos Capes, Banco de tese e dissertações e Google Acadêmico, com as seguintes palavras chaves "código de processo civil" e "Perícia contábil" e foram encontradas somente 9 ocorrências, dentre elas, um artigo repetido e outro mais voltado para a área do direito, com pouca abordagem contábil. Sobrando assim 6 estudos. E é com base nestes que a base de estudos anteriores se pautará. Acredita-se que o baixo número de artigos se deu pelo fato de ser um assunto muito recente e que começou a vigorar em março/2016.

Em 2016, ano da entrada em vigos da Lei 13.105, de 16 de março de 2015, que trata sobre o Código de Processo Civil, Mello (2016) publicou o livro intitulado A Perícia no Novo Código de Processo Civil, onde em sua introdução faz uma comparação dos artigos que tratavam sobre perícia, no Código de 1973, com os correspondentes no Código de 2015 e mais os novos recentemente cridados. Na sequência trata sobre 44 assuntos distintos, sobre perícia, abordando os artigos no antigo Código e os correspondentes no novo Código, acrescentando alguns comentários.

Pinhatti \& Scwez (2017) publicaram o artigo intitulado de Laudos Periciais Cíveis Contábeis sob o enfoque do Novo Código de Processo Civil, com o objetivo de verificar o nível de aderência dos peritos judiciais contábeis da área cível do estado do Rio Grande do Sul em relação ao artigo 473 do Código de Processo Civil, de 16 de março de 2015, no tocante à elaboração do laudo pericial contábil. Artigo este que trata sobre o que o laudo deve conter. Os resultados demonstraram que nenhum dos laudos periciais analisados atendeu a todos os aspectos contidos no artigo citado. E assim, concluiu que, embora alguns parâmetros sejam observados por grande parte dos laudos periciais analisados, ainda há muito a avançar.

Zannon et al (2018) publicaram o artigo intitulado de, A Percepção dos Juízes Paulistanos Acerca da Atuação do Perito Contador Assistente à Luz do Código de Processo Civil. O objetivo do trabalho foi o de analisar a percepção de juízes sobre a atuação do perito contador assistente, também conhecido por assistente técnico, em especial quanto ao parecer pericial contábil como meio para o convencimento motivado e auxílio no julgamento. Os resultados destacam que a atuação do perito contador assistente é relevante para o convencimento motivado e julgamento da causa, destacando que a atuação dos peritos contadores assistentes é relevante, mas existe a necessidade de aprimorarem o seu conhecimento jurídico, linguístico, experiência processual, além de uma postura mais técnica e imparcial, para que seu trabalho seja melhor compreendido e mais bem aproveitado.

Garcia, (2018) publicou o artigo intitulado Uma breve discussão sobre a perícia judicial à luz do novo código de processo civil. $\mathrm{O}$ objetivo foi fazer uma breve reflexão de algumas dessas alterações que tanto impactaram a atividade do perito judicial no seu dia a dia laboral. Tratou, dentre outros assuntos sobre a questão da escolha do perito; dos quesitos suplementares; da perícia consensual e os novos aspectos do laudo pericial.

Dias et al (2016) publicou o artigo intitulado de Novo Código de Processo Civil: Um estudo sobre os impactos na prática pericial. O objetivo foi o de trazer maior conhecimento aos leitores acerca do que é perícia contábil e prover aos leitores uma boa ferramenta para a pesquisa acerca do tema abordado. O principal achado deste trabalho consiste na importância da qualificação e constante atualização por parte do perito mediante essas alterações, tornando-se um grande desafio para esses profissionais.

Sousa Junior (2017) publicou o artigo intitulado de Aspectos Técnicos da Perícia Contábil perante o Novo Código de Processo Civil. O seu objetivo foi de debater de maneira conceitual sobre os principais aspectos técnicos da perícia contábil perante o disposto no Código de 


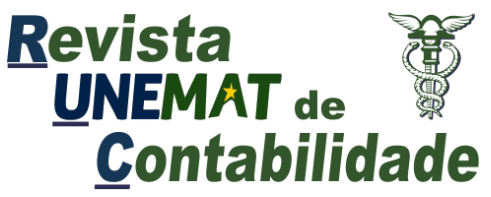

v. 8, n. 16,2019

Processo Civil (CPC). Os achado da pesquisa foram que, valendo-se de seus conhecimentos técnicos e especialidades nas ciências contábeis, o perito contador é nomeado a fim de avaliar questões patrimoniais de processos legais, a fim de oferecer ao magistrado o suporte necessário para sua tomada de decisão e sentença.

Estes trabalhos se tornaram imprescindíveis para que se pudesse fazer uma comparação entre o que foi destacado no presente trabalho e o que os autores enfatizam.

\section{A Importância da Perícia para o Poder Judiciário}

O principal objetivo da perícia judicial, de acordo com Magalhães et al (2009), é proporcionar as condições de justiça, levando em consideração os efeitos sociais dela decorrentes. O novo CPC (2015), reconhece a importância da perícia judicial através do artigo 156 no qual afirma que "o juiz será assistido por perito quando a prova do fato depender do conhecimento técnico ou científico". Assim, é perceptível a importância da perícia para o poder judicial, já que a perícia é a ferramenta que auxilia na tomada de decisão para a solução dos processos judiciais.

A perícia judicial é desenvolvida pelo perito, que ao assumir a sua função no qual tem um compromisso moral e ético para com a sociedade na qual está inserido e também para com a classe que pertence. Dessa forma, o perito tem o compromisso de estar sempre atualizado e preparado para o trabalho de boa qualidade, já que o valor social faz parte do contexto moral e ético da sua profissão. (MAGALHÃES et al, 2009).

Diante do apresentado, observa-se a importância da perícia para o poder judiciário e responsabilidade do profissional perito que a executa. A seguir, será apresentada a legislação aplicável a perícia contábil.

\subsection{A legislação aplicável a Perícia Contábil}

A legislação brasileira aplicada a perícia contábil é fundamentada através das Normas Brasileiras de Contabilidade, especificamente a NBC TP 01/2015 e NBC PP 01/2015, além do novo CPC (2015). Com isso, a seguir será apresentada a legislação aplicada a perícia contábil.

\subsubsection{As Normas Brasileiras Aplicáveis a Perícia - NBC TP 01/2015 e NBC PP 01/2015}

As Normas Brasileiras de Contabilidade aplicadas a perícia contábil estão apresentadas no NBC TP 01/2015 que objetiva estabelecer regras e procedimentos técnicos a serem observados pelo perito e na NBC PP 01/2015 que tem por objetivo estabelecer os procedimentos que são pertinentes a atuação do contador na condição de perito.

Para atuação na perícia contábil há necessidade de estar seguindo as Normas Brasileiras de Contabilidade e também observar o Código Civil, o novo CPC (2015), mais especificamente em suas seções: Seção II do perito (artigos 156 a 158); Seção X da prova pericial (artigos 464 a 484), que serão discorridos a seguir.

\subsubsection{O Novo Código de Processo Civil e a Perícia Contábil}

A perícia contábil, como outras áreas da Contabilidade, está em constante mudança. Isso é perceptível na comparação do antigo CPC (1973) e o atual CPC (2015). Com a mudança do Novo CPC 2015, os peritos são nomeados entre os profissionais legalmente habilitados e os órgãos técnicos ou científicos devidamente inscritos em cadastro mantido pelo tribunal ao qual o juiz está vinculado.

O novo CPC (2015), em sua seção II, afirma que os peritos comprovarão sua especialidade na matéria sobre que deverão opinar, mediante certidão do órgão profissional em que estiverem inscritos. Além disso, os tribunais realizarão avaliações e reavaliações periódicas para manutenção do cadastro, considerando a formação profissional, a atualização do 


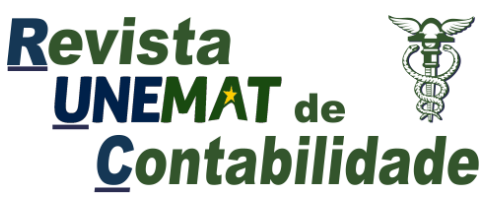

v. 8, n. 16,2019

conhecimento e a experiência dos peritos interessados. Diante dessas mudanças, é necessária uma análise sobre as principais alterações do novo CPC (2015) para a perícia contábil que deve seguir as exigências deste código para o correto desempenho de ferramenta de tomada de decisão dos magistrados.

\subsubsection{O Novo Código de Processo Civil e a Perícia Contábil - Principais Alterações}

O novo CPC (2015) trouxe algumas mudanças significativas para a perícia contábil, entre elas as principais são: a especialização do perito no objeto da perícia - art. 465, critérios para a escolha do perito, arts. 156, 375 e 465, adiantamento de 50\% dos honorários - art. 95, a perícia consensual - art. 471, a escolha do perito pelas partes em comum acordo - art. 471, a exigência da divulgação do método científico utilizado na perícia - art. 473, a prova pericial simplificada - art. 464, perito como auxiliar da justiça - art. 149, acompanhamento do trabalho do perito pelos assistentes técnicos, Art. 466, a execução de honorários periciais, Art. 515. Essas mudanças no novo CPC (2015) serão analisadas na sequência do trabalho.

\subsubsection{A Especialização do Perito no Objeto da Perícia - Art. 465}

O novo CPC (2015) discorre sobre a especialização do perito no objeto da perícia na seção X no artigo 465 em seus seis parágrafos: Art. 465. O juiz nomeará perito especializado no objeto da perícia e fixará de imediato o prazo para a entrega do laudo.

Diante do apresentado, é perceptível que as principais mudanças são: após a nomeação do perito as partes têm 15 dias para deferir e verificar se possuem algum impedimento em relação ao perito nomeado, indicar o assistente técnico e apresentar os quesitos, antes apenas 5 dias. Hoje o perito tem o prazo determinado no CPC para apresentar a proposta de honorários e a especialização no objeto da perícia e a comunicação será por meio de e-mail. Após isso, as partes também têm o prazo de 5 dias para aceitar ou contestar a proposta de honorários do perito no início dos trabalhos.

\subsubsection{Adiantamento de 50\% dos honorários - Art. 465}

O adiantamento dos honorários do trabalho do perito é tratado com maior profundidade no artigo 465 do novo CPC (2015), (...) § 4o O juiz poderá autorizar o pagamento de até cinquenta por cento dos honorários arbitrados a favor do perito no início dos trabalhos, devendo o remanescente ser pago apenas ao final, depois de entregue o laudo e prestados todos os esclarecimentos necessários.

Esta foi uma mudança significativa para os profissionais peritos no sentido de que este adiantamento será utilizado para fazer frente aos custos dos trabalhos periciais com a elaboração do laudo, que anteriormente precisava ser custeado por ele e por um período longo, dependendo do andar dos processos.

\subsubsection{A Perícia Consensual - Art. 471}

A perícia consensual ocorre quando as partes entram em acordo e escolhem o mesmo profissional para realizar a perícia. Isso é detalhado no artigo $471 \mathrm{em}$ seus 3 parágrafos do novo CPC (2015), Art. 471. As partes podem, de comum acordo, escolher o perito, indicando-o mediante requerimento, desde que: I - sejam plenamente capazes; II - a causa possa ser resolvida por auto composição.

O artigo 471 do novo CPC (2015), não tem nenhum artigo equivalente no antigo CPC (1973), porém é um acréscimo importante como opção para as partes estarem agilizando o processo. 


\subsubsection{A Exigência da divulgação do método científico utilizado na Perícia - Art. 473}

A exigência da divulgação do método científico utilizado na perícia está exposta no artigo 473 do novo CPC (2015), Art. 473. O laudo pericial deverá conter: I - a exposição do objeto da perícia; II - a análise técnica ou científica realizada pelo perito; III - a indicação do método utilizado.

Este artigo além de mudanças traz acréscimos sobre o método científico que será utilizado para a realização da perícia, demonstrando com detalhes como se chegou aos resultados apresentados e que o método e a metodologia utilizada deverão ser comprovados cientificamente e aceitos pela maioria dos profissionais.

Com o novo CPC (2015), fica explícito que o perito deve explicar o método utilizado para a realização da perícia, além de fazer em linguagem simplificada para que o magistrado e as partes compreendam o resultado. O perito deve ser imparcial, mas pode solicitar como prova todos os meios necessários, o que já era previsto no CPC (1973).

\subsubsection{A Prova Pericial simplificada - Art. 464}

A prova pericial simplificada é definida através do artigo 464 com seus 4 parágrafos do novo CPC (2015), Art. 464. A prova pericial consiste em exame, vistoria ou avaliação. § 2o De ofício ou a requerimento das partes, o juiz poderá, em substituição à perícia, determinar a produção de prova técnica simplificada, quando o ponto controvertido for de menor complexidade. §3o A prova técnica simplificada consistirá apenas na inquirição de especialista, pelo juiz, sobre ponto controvertido da causa que demande especial conhecimento científico ou técnico.

No CPC (2015), as partes podem solicitar uma substituição da perícia a ser realizada, ao magistrado, substituindo a perícia por prova técnica simplificada.

\subsubsection{Perito como Auxiliar da Justiça - Art. 149}

O perito como auxiliar de justiça aparece no artigo 149 no novo CPC (2015), Art. 149. São auxiliares da Justiça, além de outros cujas atribuições sejam determinadas pelas normas de organização judiciária, o escrivão, o chefe de secretaria, o oficial de justiça, o perito, o depositário, o administrador, o intérprete, o tradutor, o mediador, o conciliador judicial, o partidor, o distribuidor, o contabilista e o regulador de avarias.

Diante do apresentado, é nítido que o perito sempre foi auxiliar de justiça, mas com o novo CPC (2015) observa-se que o profissional contábil (contabilista) recebeu destaque no texto recebendo o status de auxiliar de justiça, o que antes recebia um termo genérico "o perito", abrangendo diversas profissões.

\subsubsection{Acompanhamento do trabalho do perito pelos assistentes técnicos, Art. 466}

Este artigo não tem correspondência no CPC de 1973. No parágrafo $2^{\circ}$ está exposto que o perito deve assegurar aos assistentes técnicos das partes o acompanhamento das diligências e dos exames que realizar, com prévia comunicação, comprovada nos autos, com antecedência mínima de 5 (cinco) dias.

\subsubsection{A forma de Escolha do Perito Judicial - Art. 465, 156 e 375}

No Código de Processo Civil de 1973 em seu artigo 145 constava que os peritos eram escolhidos entre profissionais de nível universitário, devidamente inscritos no órgão de classe competente. Já no Código de Processo Civil (2015), no artigo 465, traz o seguinte:

Art. 465. O juiz nomeará perito especializado no objeto da perícia e fixará de imediato o prazo para a entrega do laudo.

Com isso o atual CPC (2015) afirma que o perito deve ser especializado na área da 


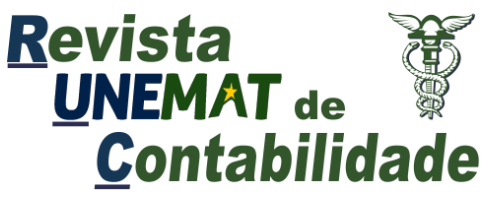

v. 8, n. 16,2019

pericia que atua. Ou seja, nível universitário não é o suficiente, é preciso ter conhecimento especializado no assunto e comprovar isto cada vez que é nomeado e aceita a incumbência.

Outro artigo que abrange a forma de escolha do perito judicial é o artigo 156 do novo CPC (2015), Art. 156. O juiz será assistido por perito quando a prova do fato depender de conhecimento técnico ou científico. $\S 1$ 1o Os peritos serão nomeados entre os profissionais legalmente habilitados e os órgãos técnicos ou científicos devidamente inscritos em cadastro mantido pelo tribunal ao qual o juiz está vinculado. Também reforça esta tese o Art. 375 que descreve que "o juiz aplicará as regras de experiência comum, subministradas pela observação do que ordinariamente acontece e, ainda, as regras de experiência técnica, ressalvado, quanto a estas, o exame pericial".

\subsubsection{A execução dos honorários periciais - Art. 515}

O CPC de 1973 em seu art. 585 destacava que os honorários periciais (dentre outros), aprovados por decisão judicial eram títulos executivos extrajudiciais, já no novo CPC trata os honorários periciais como título judicial.

\subsubsection{A resolução 233/2016 do Conselho Nacional de Justiça}

O Conselho Nacional de Justiça em sua Resolução n²33 de 13/07/2016 dispõe sobre a criação de cadastro de profissionais e órgãos técnicos ou científicos no âmbito da Justiça de primeiro e segundo graus.

Dentre as principais mudanças instituídas pode-se citar a criação do cadastro eletrônico de peritos e órgãos técnicos ou científicos (CPTEC), o qual se destina para o gerenciamento daqueles que poderão prestar serviços de perícia ou de exame técnico nos processos judiciais, nos termos do art. 156, § $1^{\circ}$, do Código de Processo Civil. Esse cadastro é dividido em áreas de especialidades e por comarca de atuação, na qual serão realizadas consultas públicas para a indicação de profissionais ou de órgãos técnicos interessados.

Desta forma o profissional Perito necessariamente terá que solicitar o seu cadastramento junto ao Tribunal de Justiça que esteja no âmbito de seu desejo de atuação para poder ser nomeado por algum juiz.

\subsubsection{A Resolução do CFC 1.502/2016, CFC 1513/2016 e NBC PG 12 (R2)}

O Conselho Federal de Contabilidade (2016), em sua NBC PG 12 (R2) que trata sobre a educação profissional continuada apresenta que o objetivo desta norma é regulamentar o Programa de Educação Profissional Continuada (PEPC) para os profissionais da contabilidade na qual visa também definir as ações que o Conselho Federal de Contabilidade (CFC) e os Conselhos Regionais de Contabilidade (CRCs) devem desenvolver para viabilizar, controlar e fiscalizar o seu cumprimento.

O CFC (2016) apresenta a Educação Profissional Continuada (EPC) como uma atividade que visa manter, atualizar e expandir os conhecimentos e competências técnicas e profissionais, as habilidades multidisciplinares e a elevação do comportamento social, moral e ético dos profissionais da contabilidade, como características indispensáveis à qualidade dos serviços prestados e ao atendimento das normas que regem o exercício da profissão contábil.

No caso da perícia contábil, a educação continuada está presente na Resolução do CFC 1.502/2016, a qual estabelece que a permanência do profissional de perícia no Cadastro Nacional de Peritos Contábeis/CNPC, controlado pelo CFC, está condicionada a obrigatoriedade do cumprimento da Educação Continuada que exige uma pontuação mínima provinda da participação em diversas atividades na área de contabilidade, que estejam ligadas a perícia contábil. 


\section{Apresentação e Análise dos Resultados}

Após a análise e a comparação do antigo CPC (1973) e o atual CPC (2015) presentes na parte 2 deste trabalho, ficam perceptíveis as mudanças que a perícia contábil passou com as alterações na lei. Para compreender as consequências dessas mudanças no atual CPC (2015), foi elaborado o questionário sobre a perícia contábil contidas no atual código de processo civil (2015), o qual foi aplicado a 10 peritos contadores que atuam na comarca de Cascavel - PR e 24 alunos concluintes do Curso de Ciências Contábeis da UNIOESTE-Campus de Cascavel, sendo que todos responderam sem identificação. O questionário contém duas partes, parte $\mathrm{A}$ com 8 questões de múltipla escolha e parte B com 3 questões abertas/subjetivas, subdividas em mais 3 indagações, totalizando 9 questões.

\subsection{Apresentação e análise dos resultados da parte A do questionário}

Inicialmente foi analisada a parte A do questionário, que teve como objetivo a identificação do perfil dos entrevistados e também a sua proximidade com a perícia contábil, conforme gráficos exposto a baixo.

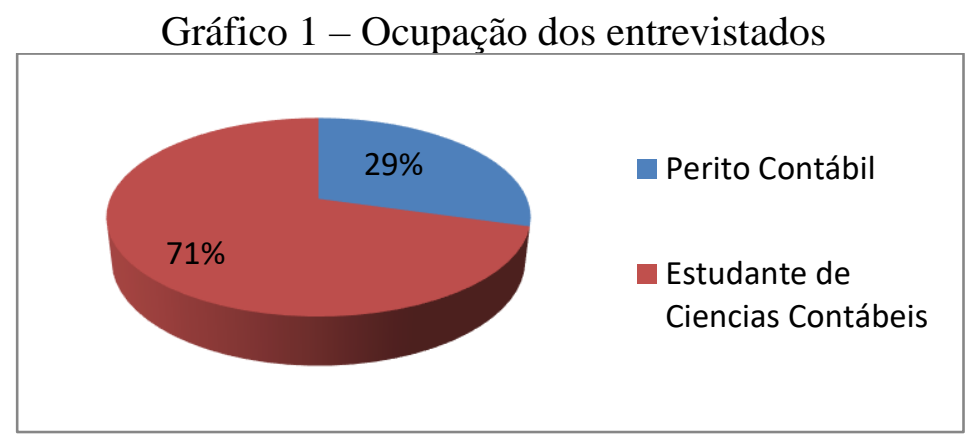

Fonte: Dados da pesquisa, (2017).

A primeira questão solicitou a ocupação dos entrevistados e no Gráfico 1 pode-se verificar que 10 entrevistados são peritos contábeis que atuam na comarca de Cascavel/PR e 24 são estudantes concluintes de Ciências Contábeis da UNIOESTE -Cascavel.

Gráfico 2 - Gênero dos peritos contábeis

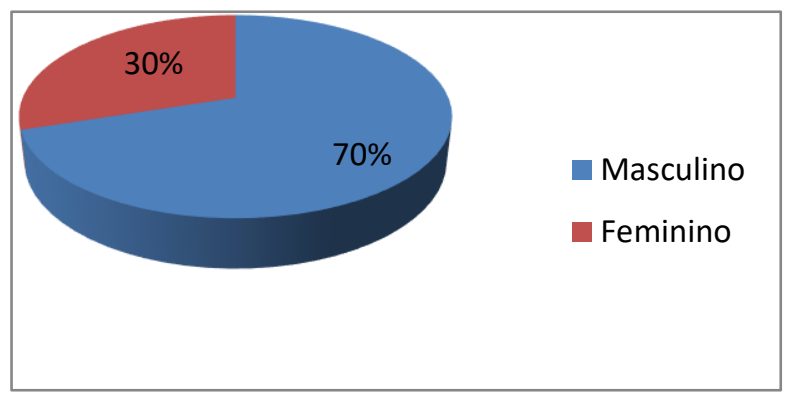

Fonte: Dados da pesquisa, (2017).
Gráfico 3 - Gênero dos estudantes de ciências contábeis

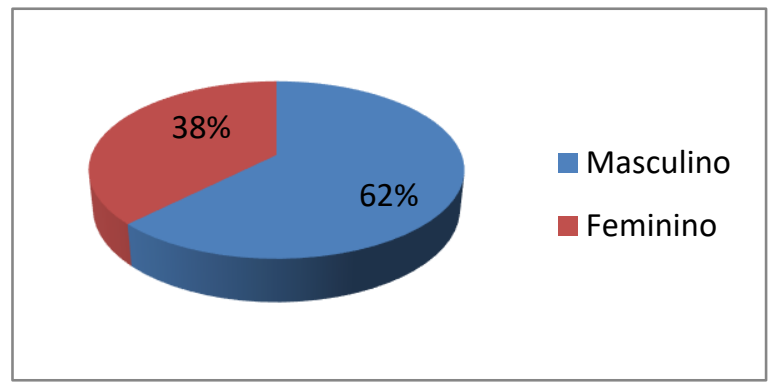

Fonte: Dados da pesquisa, (2017).

A segunda questão teve por objetivo identificar o gênero dos entrevistados, como se pode visualizar nos Gráfico 2, referente aos peritos contábeis e Gráfico 3, os estudantes concluintes de Ciências Contábeis. Nestes Gráficos ficou perceptível que a maiorias dos entrevistados, sendo 7 peritos contadores e 14 dos estudantes concluintes de Ciências Contábeis 
são do sexo masculino. Demonstrando que a profissão de Contador é ainda essencialmente formada por homens, $70 \%$ para os peritos e $58 \%$ para os estudantes. No caso do sexo feminino foram 3 peritas e 9 estudantes que responderam ao questionário. Confirmando os dados fornecidos pelo CRCPR/2019, onde dos contadores, 58,68\% são do sexo masculino e 41,31\% do sexo feminino. Já em relação aos técnicos em contabilidade a diferença é bem maior, 71,74\% são do sexo masculino e $28,25 \%$ do sexo feminino. Contando com todos os profissionais registrados no CRCPR, em 08/2019, tem-se, 61,99\% do sexo masculino e 38,01\% do sexo feminino.

A terceira questão identificou a faixa etária dos peritos contadores (Gráfico 4) e dos estudantes concluintes de Ciências Contábeis (Gráfico 5).

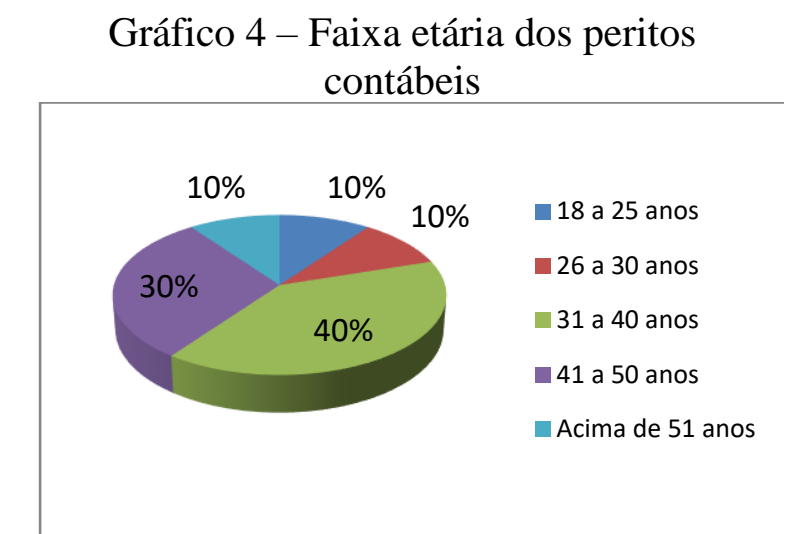

Fonte: Dados da pesquisa, (2017).
Gráfico 5 - Faixa etária dos estudantes de ciências contábeis

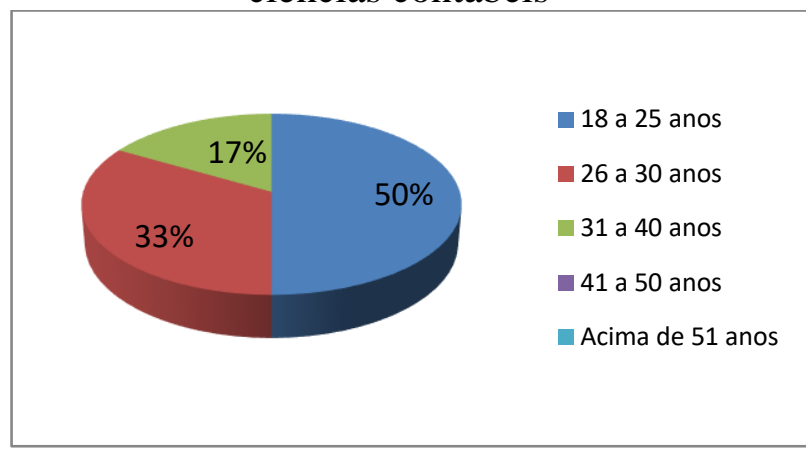

Fonte: Dados da pesquisa, (2017).

No Gráfico 4, observa-se que $70 \%$ dos peritos contadores tem entre 31 a 50 anos de idade. No Gráfico 5, a faixa etária dos estudantes concluintes de Ciências Contábeis é de 50\% para a faixa etária entre 18 a 25 anos, $33 \%$ possui entre 26 a 30 anos e apenas $17 \%$ tem idade entre 31 a 40 anos. Nenhum estudante tem idade acima de 41 anos.

A pergunta 4 visou mostrar o grau de instrução dos peritos contadores, conforme o Gráfico 6 e dos estudantes concluintes de Ciências Contábeis, segundo o Gráfico 7. Onde demonstrou que os peritos contadores (Gráfico 6), são todos especialistas, já que $90 \%$ dos entrevistados fizeram uma pós-graduação e $10 \%$ tem mestrado e doutorado.

Gráfico 6 - Grau de instrução dos peritos contábeis

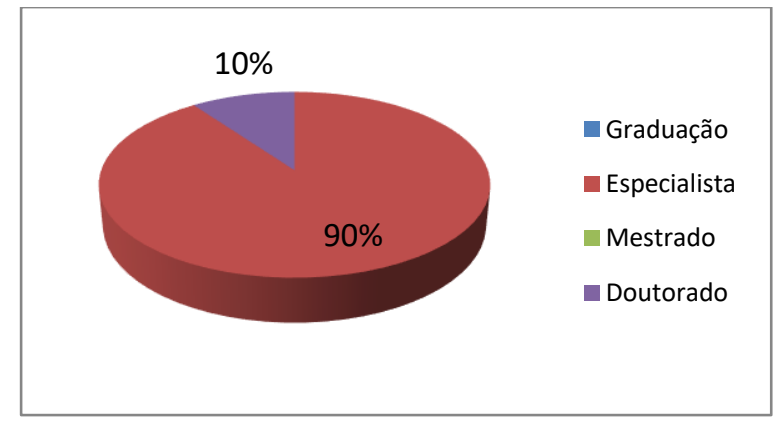

Gráfico 7 - Grau de instrução dos estudantes de ciências contábeis

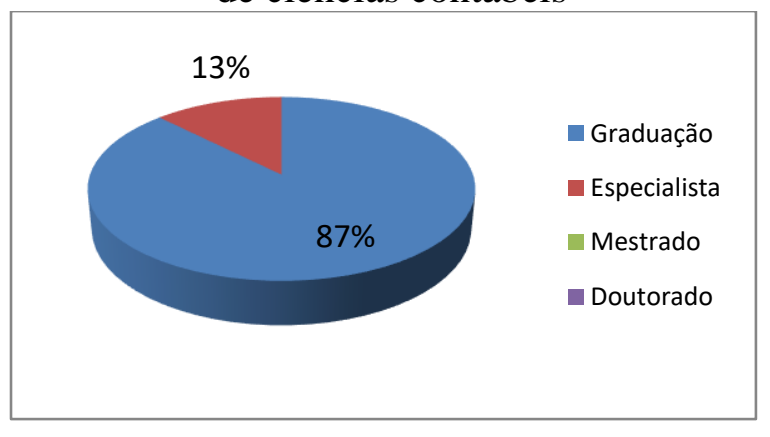


Fonte: Dados da pesquisa, (2017).

Fonte: Dados da pesquisa, (2017).

Ou seja, nenhum dos peritos contábeis parou no nível de graduação. Os estudantes têm 87\% nível de graduação e 13\% já possuem especialização (Gráfico 7) e consequentemente uma graduação anterior.

A quinta questão indagou-se aos entrevistados sobre os anos de experiência na área de perícia contábil para os peritos contadores (Gráfico 8) e estudantes (Gráfico 9)

Gráfico 8 - Experiência na área de perícia contábil dos peritos contábeis

\begin{tabular}{ll|}
$\square 0-5$ anos & $\square 6-10$ anos \\
$\square 11-15$ anos & $\square$ Mais de 15 anos \\
$\square$ Sem experiência & $\square$ Tem interesse na área \\
$10 \%$ & $60 \%$ \\
$20 \%$ & $60 \%$ \\
&
\end{tabular}

Fonte: Dados da pesquisa, (2017).
Gráfico 9 - Experiência na área de perícia contábil dos estudantes de ciências contábeis

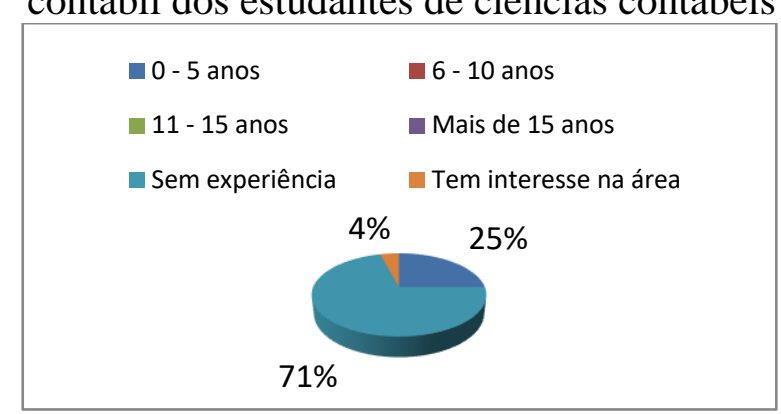

Fonte: Dados da pesquisa, (2017)

Nestes Gráficos, observa-se que 6 peritos contadores tem entre 0 a 5 anos de experiência na área de perícia contábil. Enquanto que 17 dos estudantes concluintes de Ciências Contábeis não tem experiência na área, 6 dos estudantes tem algum conhecimento na área, mas apenas 1 tem interesse na área de perícia contábil.

A pergunta 6 buscou analisar qual é o maior atrativo que os entrevistados observam na perícia contábil. Os resultados foram os seguintes: peritos contábeis (Gráfico 10) e estudantes concluintes de ciência contábeis (Gráfico 11). No Gráfico 10 os peritos contábeis observam que a perícia contábil, é uma especialização na área contábil, devido a autonomia que a perícia contábil proporciona a quem atua nessa área e lhes confere um determinado status perante a classe. Enquanto no Gráfico 11, a maioria dos estudantes concluintes de ciências contábeis, (8), respondeu que a perícia pode proporcionar remuneração alta.

Gráfico 10 - Maior atrativo na perícia contábil para os peritos contábeis

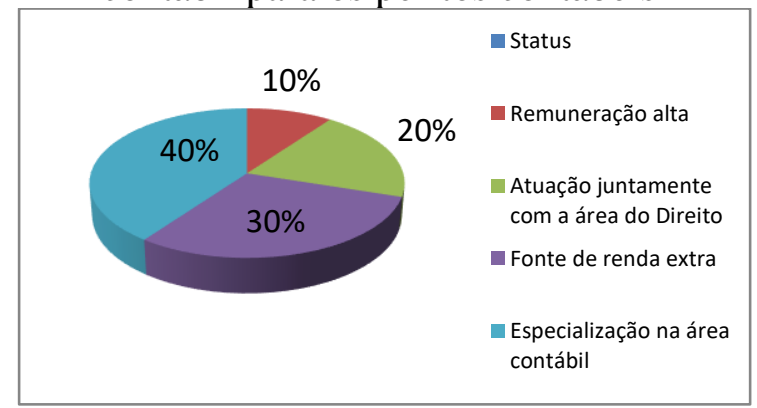

Fonte: Dados da pesquisa, (2017).
Gráfico 11 - Maior atrativo na perícia contábil para os estudantes de C. contábeis

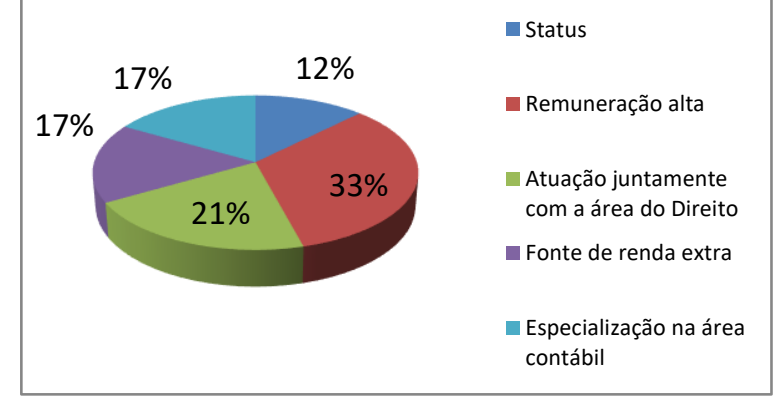

Fonte: Dados da pesquisa, (2017).

A pergunta 7 visou mostrar o conhecimento das alterações que o novo Código de Processo Civil (2015) trouxe para a perícia contábil. As opiniões dos peritos contadores são observadas no Gráfico 12 e a opinião dos estudantes concluintes de Ciências Contábeis segundo o Gráfico 13. Nestes Gráficos os peritos contadores em sua maioria 9 responderam que tem pleno conhecimento do assunto (Gráfico 12). Por outro lado, nenhum estudante afirmou ter pleno conhecimento, mas 14 estudantes disseram que já leram sobre o assunto e ouviram 
comentários sobre as alterações do atual CPC, principalmente em sala de aula. (Gráfico 13).

Gráfico 12 - Alterações do CPC (2015) na perícia contábil percebidas pelos peritos

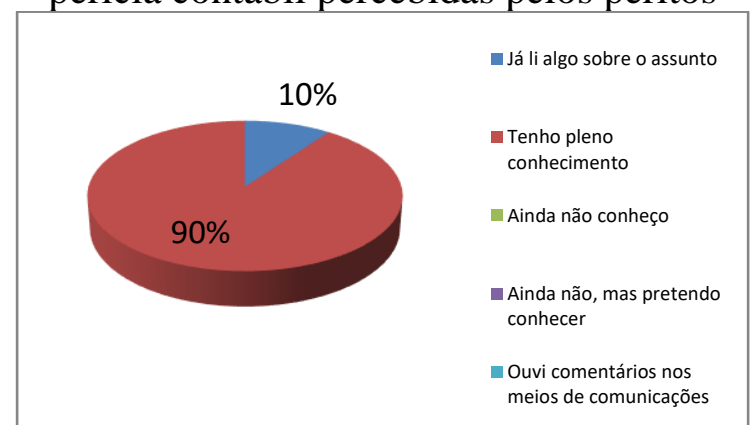

Fonte: Dados da pesquisa, (2017).
Gráfico 13 - Alterações do CPC (2015) na perícia contábil percebidas pelos estudantes

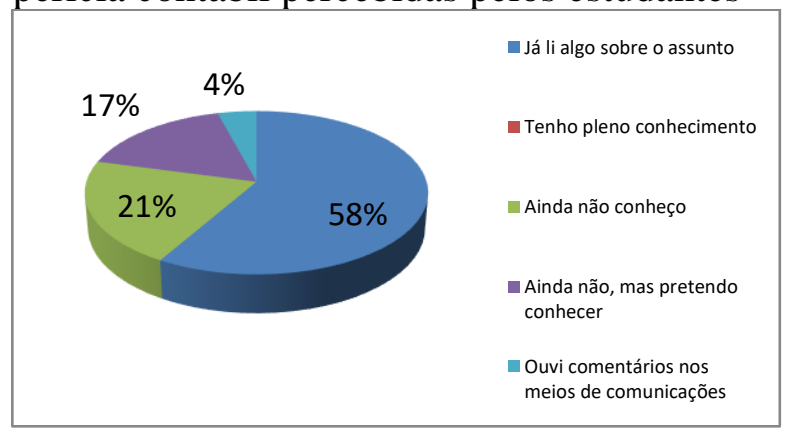

Fonte: Dados da pesquisa, (2017).

A última questão do questionário, da parte $\mathrm{A}$, indagou aos entrevistados sobre a sua visão sobre a perícia contábil. Os resultados para peritos contábeis (Gráfico 14) e estudantes concluintes de ciência contábeis (Gráfico 15).

Gráfico 14 -Visão pessoal da perícia contábil pelos peritos contábeis

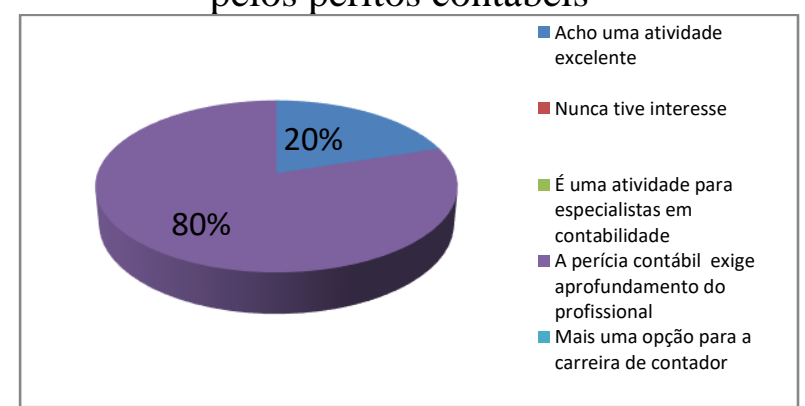

Fonte: Dados da pesquisa, (2017).
Gráfico 15 - Visão pessoal da perícia contábil pelos estudantes de C. Contábeis

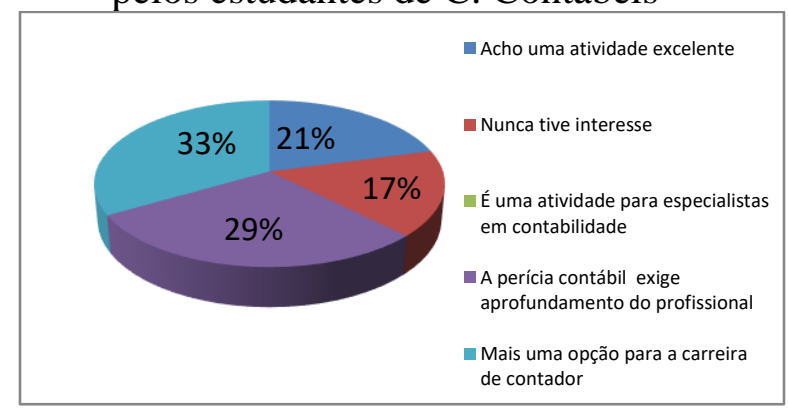

Fonte: Dados da pesquisa, (2017).

A visão pessoal de perícia para 8 peritos contadores é de que exige um aprofundamento maior por parte do profissional que está na área e para 2 peritos é uma atividade excelente, conforme Gráfico 14. Já, no Gráfico 15, os estudantes concluintes tiveram opiniões mais divergentes, mas a maioria, 8 estudantes afirmaram que é mais uma opção para a carreira do contador, enquanto nenhum afirmou que a perícia seja uma atividade para especialistas em contabilidade.

\subsection{Apresentação e análise dos resultados da parte $B$ do questionário}

$\mathrm{Na}$ parte $\mathrm{B}$ do questionário estão 3 questões abertas, subdivididas em mais 3 indagações, totalizando 9 questões que serão apresentadas nas Tabelas a baixo e analisadas a seguir.

A questão 9 discorre sobre o Código de Processo Civil (2015), que em seu artigo 465 trata do seguinte: "O juiz nomeará perito especializado no objeto da perícia e fixará de imediato o prazo de entrega do laudo". Item II do Parágrafo 2 "Deverá apresentar currículo com comprovação de especialização"; desta forma o candidato a perito judicial deverá comprovar experiência ou ainda ser especialista no objeto da perícia, deixando claro que perícia judicial não deve ser exercida por leigos. No item A dessa pergunta foi indagado a opinião dos entrevistados e foi obtido as seguintes respostas: no Quadro 1, observa-se que os peritos 
contadores são todos favoráveis ao artigo 465 do CPC (2015), já que acham justo esse artigo. Também no Quadro 1, 20 estudantes afirmaram que está correto, 3 que está incorreto e 1 não expressou opinião sobre essa questão. Neste diapasão pode-se destacar ainda os artigos do NCPC, 156- "o juiz será assistido por perito quando a prova do fato depender de conhecimento técnico ou científico" e 468- "o perito pode ser substituído quando: I- faltar-lhe conhecimento técnico ou científico", que reforçam a questão da necessidade de especialidade no objeto da perícia.

Neste sentido Mello (2016, p. 110) que

há evidente contradição entre ambos dispositivos legais (art. 156 e 468), sendo inapropriada a indicação de apenas "possibilidade" de substituição do profissional quando verificada a inexistência de seu conhecimento técnico ou científico, visto que a perícia somente tem lugar quando a prova de fato depender dessas habilidades.

Também vale destacar que de acordo com o Art. 156 o juiz, no ato da nomeação deve indicar o perito que esteja no cadastro mantido pelo Tribunal. Isto quer dizer que o NCPC não permite mais a livre escolha do juiz, mesmo se não atender os requisitos de capacidade técnica ou científica. (Mello, 2016). Mas logicamente o juiz, em sua função de julgar, irá tomar a melhor atitude, escolhendo quem de fato tem especialização no objeto da perícia.

Quadro 1 - Análise da opinião dos peritos e estudantes sobre o artigo 465 do CPC/2015

\begin{tabular}{|c|l|c|l|c|}
\hline Categorias & \multicolumn{1}{|c|}{ Perito } & $\%$ & \multicolumn{1}{c|}{ Estudantes } & $\%$ \\
\hline $\begin{array}{c}\text { A }- \\
\text { Correto }\end{array}$ & $\begin{array}{l}\text { todos foram unanimes ao afirmar } \\
\text { que legislação deve exigir } \\
\text { especialização para realizar a perícia } \\
\text { contábil. Assim, leigos não podem } \\
\text { realizar esse trabalho. }\end{array}$ & 100 & $\begin{array}{l}\text { só seria oferecido trabalho com alto nível, } \\
\text { irá retirar do mercado os não qualificados, } \\
\text { atividade só para especialistas, evitar } \\
\text { prejuízos para as partes no processo, seria } \\
\text { para profissionais com conhecimento } \\
\text { técnico formal. }\end{array}$ & 83 \\
\hline $\begin{array}{c}\text { B }- \\
\text { Incorreto }\end{array}$ & & $\begin{array}{l}\text { É incorreto porque apenas especialistas } \\
\text { poderão atuar nessa área, isso filtra os } \\
\text { profissionais. Além disso, um bacharel em } \\
\text { contabilidade está apto para fazer perícia. }\end{array}$ & 13 \\
\hline $\begin{array}{c}\text { C-Sem } \\
\text { opinião }\end{array}$ & & $\begin{array}{l}\text { Devido a legislação ser recente, um } \\
\text { estudante ainda não tem opinião formada } \\
\text { sobre o assunto. }\end{array}$ & 4 \\
\hline
\end{tabular}

Fonte: Dados da pesquisa.

No item B da questão 9 foi feita a seguinte pergunta "Se você almejasse entrar para carreira de perito, quais atitudes que você iria tomar para conseguir este objetivo?", as respostas dos peritos e estudantes concluintes foram as seguintes, de acordo com o Quadro 2, respectivamente: 4 peritos responderam que necessitam estudar e se especializar e 6 responderam estudar e obter experiência prática. 16 estudantes responderam que devem estudar e se especializar, 3 afirmaram estudar e experiência na prática, 2 consideraram que deve-se estudar e entrar no mercado e 3 não responderam essa questão.

Conforme Dias, et al, (2016)

os artigos 156, 371, 465, 473 e 479, privilegiam o conhecimento do profissional que labuta nesta seara profissional; exigem capacitação técnica adequada e competente; estimula a formação profissional continuada e a busca por especialização; reconhece o profissional possuidor de experiência anterior; e, fortalece a valorização da prova pericial.

E assim pode-se verificar que tanto os peritos quanto os estudantes concluintes estão conscientes que o auxiliar do juízo, o perito e o das partes, o assistente técnico, devem 
apresentar a especialização no objeto da perícia, quando de sua nomeação. Mesmo porque a função de perito servirá como "o olho tecnológico científico do Magistrado, a mão longa da justiça, enfim, o apoio científico ao ilustre condutor judicial”. (Hoog, 2017, p.118).

Quadro 2 - Análise das atitudes dos peritos e estudantes para entrar na carreira de perito

\begin{tabular}{|c|c|c|c|c|}
\hline Categorias & Peritos & $\%$ & Estudantes & $\%$ \\
\hline $\begin{array}{l}\text { A - Estudar e } \\
\text { se especializar }\end{array}$ & $\begin{array}{l}\text { eles afirmaram que os profissionais } \\
\text { devem estudar para entrar na área, os } \\
\text { quais devem se manter estudando. }\end{array}$ & 40 & $\begin{array}{l}\text { esta análise verificou que estudar e } \\
\text { aprofundar os conhecimentos buscando } \\
\text { uma especialização na área é a melhor } \\
\text { atitude a ser tomada para entrar na } \\
\text { carreira de perito. }\end{array}$ & 67 \\
\hline $\begin{array}{l}\text { B - Estudar e } \\
\text { experiência } \\
\text { prática }\end{array}$ & $\begin{array}{l}\text { esta categoria foi a mais escolhida, } \\
\text { porque afirmaram o que fizeram } \\
\text { para entrar nessa carreira. Além de } \\
\text { estudar, buscaram trabalhar com } \\
\text { profissionais que já estavam na área. }\end{array}$ & 60 & $\begin{array}{l}\text { eles acreditam que além de estudar é } \\
\text { preciso ter uma experiência prática na } \\
\text { área de perícia. }\end{array}$ & 13 \\
\hline $\begin{array}{l}\mathrm{C} \text { - Estudar e } \\
\text { entrar no } \\
\text { mercado }\end{array}$ & & & $\begin{array}{l}\text { eles afirmaram que além de estudar é } \\
\text { interessante fazer a prova de perito e } \\
\text { entrar em contato com juízes. }\end{array}$ & 8 \\
\hline D - Nenhuma & & & $\begin{array}{l}\text { eles responderam que não pretendem } \\
\text { atuar nessa área. }\end{array}$ & 13 \\
\hline
\end{tabular}

Fonte: Dados da pesquisa.

Para concluir a pergunta 9, no item $\mathrm{C}$ foi questionado o seguinte: "Na sua opinião, estas exigências irão limitar a entrada de novos profissionais no ramo de perícia? Porque?". No Quadro 3, 2 peritos responderam que sim e 8 que não. Por outo lado, os estudantes chegaram as seguintes afirmações, também conforme Quadro 3, 14 responderam sim, 6 não, 3 talvez e 1 não teve opinião.

Realmente as chegaram a conclusão de que as exigências não estão se referindo a limitações e sim retardamento da possível entrada, visto que há necessidade de se especializar, ter experiência e prática, principalmente aos estudantes, pois há necessidade de realizar o exame de suficiência, obter o registro no $\mathrm{CRC}$, realizar a prova de perito e estar no Cadastro Nacional de Peritos e ainda comprovar que é especialista no objeto da perícia. E assim, para que o perito possa realmente ajudar o juízo a tomar a sua decisão "há necessidade de o perito nomeado possuir ou obter maior conhecimento e experiência em assuntos distintos, levando-o a uma visão ampla sobre a perícia". (Zannon et al, 2018, p.126).

Quadro 3 - Limitações da entrada na carreira de perito segundo peritos e estudantes

\begin{tabular}{|c|c|c|c|c|}
\hline Categorias & Peritos & $\%$ & Estudantes & $\%$ \\
\hline $\mathrm{A}-\mathrm{Sim}$ & $\begin{array}{l}\text { eles afirmaram que as } \\
\text { exigências irão limitar o } \\
\text { mercado apenas para os } \\
\text { aventureiros que não tem } \\
\text { conhecimento na área. }\end{array}$ & 20 & $\begin{array}{l}\text { esta análise verificou que a limitação da } \\
\text { entrada de novos profissionais na área da } \\
\text { perícia é devido a exigência da prova de } \\
\text { perícia, além do registro no CRC. A } \\
\text { experiência de alguém que não tem } \\
\text { experiência. E a especialização que retarda a } \\
\text { entrada desse profissional na área. }\end{array}$ & 58 \\
\hline B - Não & $\begin{array}{l}\text { eles destacaram que as } \\
\text { exigências não limitam a } \\
\text { entrada de novos } \\
\text { profissionais na área, pois os } \\
\text { especialistas podem atuar } \\
\text { sem problemas. }\end{array}$ & 80 & $\begin{array}{l}\text { eles acreditam que quem estudar e se dedicar } \\
\text { conseguirá entrar nessa área. }\end{array}$ & 25 \\
\hline $\mathrm{C}$ - Talvez & & & $\begin{array}{l}\text { eles afirmaram talvez porque não é fácil } \\
\text { conseguir a experiência necessária. }\end{array}$ & 13 \\
\hline
\end{tabular}


D - Sem opinião

alguns não responderam.

Fonte: Dados da pesquisa.

A questão 10 fez referência ao artigo 156 do atual CPC (2015), que afirmou que o perito deverá cumprir com as exigências legais (certidões negativas de órgãos federais, estaduais, municipais, trabalhistas e certidão de regularidade profissional, e os órgãos técnicos ou científicos (no caso da Contabilidade o CFC/CRCs), deverá se manter no cadastro no Tribunal de Justiça. O CFC iniciou o Cadastro Nacional de Peritos Contábeis - CNPC e quem se cadastrar terá que comprovar a pontuação exigida em Educação Continuada. No item A da questão 10, foi elaborada no sentido de buscar a opinião dos entrevistados, no Quadro 4, todos os peritos são unanimes e tiveram opinião a favor das exigências legais do artigo 156 do atual CPC. Já, os estudantes possuem opiniões mais variadas, também conforme Quadro 4, 17 estudantes tiveram opinião a favor, 5 tiveram opinião contrária e 2 não expressaram opinião.

Segundo os resultados do trabalho de Silva e Martins, a maioria considerou que a iniciativa (de exigir a educação continuada) contribui para aumentar sua qualificação profissional, além de atestar a eficácia da medida em aumentar a credibilidade do perito contábil diante das partes interessadas. Também foi destacado, pelos respondestes, que os programas de educação a distâncias (EAD) deveriam ser aprimorados e expandidos. O trabalho destacou o perfil dos respondestes, demonstrando que poucos tinham a prática de educação continuada, para o seu aperfeiçoamento e aquisição de novos conhecimentos. (Silva e Martins, 2018).

E assim, os peritos estarão mais informados e qualificados, aptos para oferecer serviços com maior qualidade, atendendo as expectativas da justiça.

Quadro 4 - Análise da educação continuada na área de perícia segundo os peritos e estudantes

\begin{tabular}{|c|l|c|l|c|}
\hline Categorias & \multicolumn{1}{|c|}{ Peritos } & $\%$ & \multicolumn{1}{|c|}{ Estudantes } & $\%$ \\
\hline $\begin{array}{c}\text { A - Opinião a } \\
\text { favor }\end{array}$ & $\begin{array}{l}\text { todos afirmaram que a educação } \\
\text { continuada é ótima para os } \\
\text { profissionais que atuam na perícia, } \\
\text { além de ser uma forma de } \\
\text { regulamentar a profissão. }\end{array}$ & $\begin{array}{l}\text { eles responderam que é importante } \\
\text { pertinente para confirmar a } \\
\text { qualificação do profissional. }\end{array}$ & 71 \\
\hline $\begin{array}{c}\text { B - Opinião } \\
\text { contrária }\end{array}$ & & & $\begin{array}{l}\text { eles acreditam que é uma } \\
\text { burocracia desnecessária. }\end{array}$ & 21 \\
\hline C-Sem opinião & & & eles não expressaram sua opinião. & 8 \\
\hline
\end{tabular}

Fonte: Dados da pesquisa.

No item B da questão 10 foi feita a seguinte indagação "Em sua opinião as exigências do Novo Código de Processo Civil são benéficas para os profissionais que já atuam na pericias? Porque?".

No Quadro 5, 3 peritos expressaram opinião afirmativa e 7 opinião parcial. Enquanto 13 estudantes possuem opinião afirmativa, 3 com opinião negativa, 5 não opinaram e 3 tem opinaram parcialmente.

O NCPC veio para formalizar diversas alterações em seu texto original, ao longo de 42 anos (1973-2015). E "ao menos em teoria, o NCPC tende a apresentar um controle mais presente e intrínseco da perícia contábil, com avaliações periódicas de competência e alocações de peritos realmente aptos e técnicos para a realização dos trabalhos periciais". (Sousa Junior, et al, 2017). E assim, verificando as respostas dos peritos, a maioria pensa que não benecifiam, e poder-se-ia acrescentar que diretamente não, porque exigem mais deles, mas indiretamente sim, pelo fato que será forçado a buscar qualificação, demonstrado estarem aptos a exercer este trabalho com maestria.

Quadro 5 - Análise das mudanças benéficas do atual CPC (2015) para os peritos que já atuam 
na área segundo os peritos e estudantes

\begin{tabular}{|c|l|l|l|c|}
\hline Categorias & \multicolumn{1}{|c|}{ Peritos } & $\%$ & \multicolumn{1}{c|}{ Estudantes } & $\%$ \\
\hline $\begin{array}{c}\text { A - Opinião } \\
\text { a favor }\end{array}$ & $\begin{array}{l}\text { são favoráveis porque quem atua já } \\
\text { está qualificado e atende as novas } \\
\text { exigências. }\end{array}$ & 30 & $\begin{array}{l}\text { esses profissionais já têm experiência, além } \\
\text { das exigências restringirem a entrada de } \\
\text { novos profissionais na área. }\end{array}$ & 54 \\
\hline $\begin{array}{c}\text { B - Opinião } \\
\text { negativa }\end{array}$ & $\begin{array}{l}\text { essas exigências não beneficiam } \\
\text { os peritos que já atuam. }\end{array}$ & 70 & $\begin{array}{l}\text { eles acreditam que exigirá mais da parte dos } \\
\text { profissionais que já atuam na área de perícia. }\end{array}$ & 13 \\
\hline $\begin{array}{c}\text { C - Não tem } \\
\text { opinião }\end{array}$ & & $\begin{array}{l}\text { eles afirmaram não ter conhecimento } \\
\text { suficiente para formar opinião. }\end{array}$ & 21 \\
\hline $\begin{array}{c}\text { D- Opinião } \\
\text { parcial }\end{array}$ & $\begin{array}{l}\text { eles acreditam que beneficia em partes, pois } \\
\text { restringirá o mercado para a entrada de novos } \\
\text { profissionais, por outro lado, exigirá mais da } \\
\text { parte dos profissionais que já atuam. }\end{array}$ & 13 \\
\hline
\end{tabular}

Fonte: Dados da pesquisa.

A última pergunta faz uma comparação entre o CPC de 1973 e o atual CPC de 2015, a qual apresenta "outra mudança que houve com a entrada em vigor do Novo Código de Processo Civil, relacionada a formação do perito: No Código anterior de 1973, em seu artigo 145 , parágrafo $1^{\circ}$, constava que "Os peritos serão escolhidos entre profissionais de nível universitário, devidamente inscritos no órgão de classe competente". Já no Código de Processo Civil (2015), no artigo 465, traz o seguinte: "O juiz nomeará perito especializado no objeto da perícia”. Desta forma, deixa implícita a formação acadêmica específica, mas deixa claro que exige um técnico especializado no objeto da perícia e que para exercer a atividade de perito, há necessidade de ser um profissional que domina a técnica relacionada ao objeto da perícia. No item A dessa pergunta foi indagado a opinião dos entrevistados e foi obtido as seguintes respostas. No Quadro 6, 5 peritos acreditam que é importante para o profissional e para a justiça e 5 peritos acham que impede que leigos exercem a atividade. Para 19 estudantes é importante para o profissional e para a justiça, 2 que impede leigos de exercer a atividade e 3 não expressaram sua opinião.

Quadro 6 - Opinião dos entrevistados sobre os Art. 1143 do CPC/73 e 465 do CPC/2015

\begin{tabular}{|c|c|c|c|c|}
\hline Categorias & Peritos & $\%$ & Estudantes & $\%$ \\
\hline $\begin{array}{c}\text { A - Importante } \\
\text { para o } \\
\text { profissional e } \\
\text { para a justiça }\end{array}$ & $\begin{array}{c}\text { nesta categoria afirmaram que serão } \\
\text { convocados os profissionais } \\
\text { especializados, não apenas os que tem } \\
\text { a confiança do juiz. }\end{array}$ & 50 & $\begin{array}{c}\text { eles responderam que melhora a } \\
\text { qualidade do laudo pericial, pois } \\
\text { será realizado por um perito } \\
\text { especializado no assunto. }\end{array}$ & 79 \\
\hline $\begin{array}{c}\text { B - Impede que } \\
\text { leigos exercem a } \\
\text { atividade }\end{array}$ & $\begin{array}{c}\text { eles afirmaram que não basta ter nível } \\
\text { universitário, tem que ter conhecimento } \\
\text { técnico do assunto, impedindo que } \\
\text { leigos atuem nessa área. }\end{array}$ & 50 & $\begin{array}{c}\text { A análise revela que acreditam } \\
\text { que leigos não terão espaço para } \\
\text { atuar na perícia, apenas os } \\
\text { peritos especialistas. }\end{array}$ & 8 \\
\hline C-Sem opinião & $\begin{array}{c}\text { Alguns não expressaram sua } \\
\text { opinião sobre o assunto. }\end{array}$ & 13 \\
\hline
\end{tabular}

Fonte: Dados da pesquisa.

No item B da questão 11 ao ser realizada a pergunta "Na sua opinião a mudança de "profissional de nível superior" para "perito especializado" será prejudicial ou benéfico para a atividade de perícia? Porque?", O Quadro 7 apresenta que os peritos são unanimes em concordar com a mudança de perito técnico para perito especializado no objeto da perícia. 13 estudantes acharam que é benéfico, apenas 3 acreditam que seja prejudicial e 8 não expressaram sua opinião.

Quadro 7 - Mudança de "profissional de nível superior" para "perito especializado" segundo os entrevistados

\begin{tabular}{|c|c|c|c|c|}
\hline Categorias & Peritos & $\%$ & Estudantes & $\%$ \\
\hline
\end{tabular}




\begin{tabular}{|c|c|c|c|c|}
\hline A - Benéfico & $\begin{array}{c}\text { Todos afirmaram ser benéfico a } \\
\text { mudança porque para atuar na } \\
\text { área é necessário ser especialista } \\
\text { no assunto. }\end{array}$ & 100 & $\begin{array}{c}\text { eles acreditam que a mudança é benéfica } \\
\text { porque exige maior conhecimento e } \\
\text { profissionalismo do perito especializado. }\end{array}$ & 54 \\
\hline B - Prejudicial & & $\begin{array}{c}\text { Nesta categoria, eles acham que seja } \\
\text { prejudicial porque abre margem para } \\
\text { profissionais de outras áreas atuar na } \\
\text { área da contabilidade. }\end{array}$ & 13 \\
\hline $\begin{array}{c}\text { C-Sem } \\
\text { opinião }\end{array}$ & & $\begin{array}{c}\text { Alguns não expressaram sua opinião } \\
\text { sobre o assunto. }\end{array}$ & 33 \\
\hline
\end{tabular}

Fonte: Dados da pesquisa.

Para concluir, no item $\mathrm{C}$ da questão 11, foi feita a seguinte questão "Na sua opinião qual das duas formas irá convencer melhor o Juiz na hora da escolha do perito? Nível universitário ou perito especializado no objeto da perícia? Porque?". Com isso, no Quadro 8, todos os peritos afirmaram perito especializado. Por outro lado 20 estudantes responderam que a preferência seria perito especializado, 2 afirmaram que depende do juiz e 2 não expressaram sua opinião.

Quadro 8 - Nível universitário ou perito especializado segundo os entrevistados

\begin{tabular}{|c|c|c|c|c|}
\hline Categorias & Peritos & $\%$ & Estudantes & $\%$ \\
\hline $\begin{array}{c}\text { A - Perito } \\
\text { especializado }\end{array}$ & $\begin{array}{c}\text { todos afirmaram perito } \\
\text { especializado no objeto da perícia, } \\
\text { porque a nova exigência é para } \\
\text { peritos que além de experiência } \\
\text { devem ser especialistas no assunto. }\end{array}$ & 100 & $\begin{array}{c}\text { eles responderam perito especializado } \\
\text { no objeto da perícia porque é o } \\
\text { profissional mais qualificado para } \\
\text { realizar o trabalho. }\end{array}$ & 83 \\
\hline $\begin{array}{c}\text { B - Depende do } \\
\text { juiz }\end{array}$ & & $\begin{array}{c}\text { Nesta categoria, eles destacaram que } \\
\text { depende da necessidade do juiz que } \\
\text { pode escolher qualquer um. }\end{array}$ & 8 \\
\hline $\begin{array}{c}\text { C-Sem } \\
\text { opinião }\end{array}$ & & $\begin{array}{c}\text { Alguns não expressaram sua opinião } \\
\text { sobre o assunto. }\end{array}$ & 8 \\
\hline
\end{tabular}

Fonte: Dados da pesquisa.

Englobando os dados dos Quadros 6 a 8 pode-se inferir que da forma com estava descrito no CPC (1973), o estudante que concluísse o curso superior estaria apto para exercer a função de perito, não necessitando comprovar mais nada. Já no que diz respeito ao CPC (2015), o profissional terá que comprovar, mediante currículo, que é especializado no objeto da perícia. Realmente estará restringindo e também protelando a entrada de novos profissionais na área de perícias, pelo fato que este terá que esperar até que se torne especializado no objeto da perícia, e isto pode retardar um pouco o seu ingresso.

Neste sentido "o novo CPC reconhece a importância da Perícia Contábil, exigindo maior transparência na indicação do perito e reforçando a necessidade de conhecimento tpecnico especializado. Dias et al, (2016).

No contexto do novo CPC, será nomeado o profissional que demonstrar conhecimento especializado na área, independente da formação universitária. (Garcia, 2018).

Diante do exposto, é perceptível que os peritos e os estudantes têm visões diferentes sobre as novas exigências do atual CPC (2015). Sob a ótica dos peritos, que já atuam na área de perícia, essas mudanças são benéficas porque apenas profissionais especializados com experiência podem atuar na área de perícia, isso fortalece a profissão. Por outro lado, na visão dos estudantes concluintes do curso de ciências contábeis as novas exigências dificultam a entrada de novos profissionais, já que os mesmos além da prova do CRC terão que fazer a prova específica de perícia, fazer cursos de especialização nessa área e o principal ter experiência na 


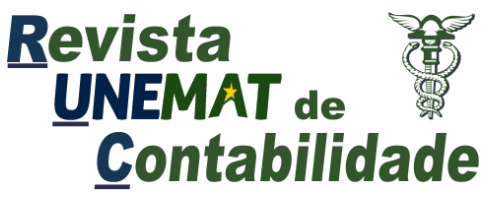

v. 8, n. 16,2019

área em que deseja começar a atuar.

\section{CONCLUSÕES}

Diante do apresentado, este trabalho teve como objetivo principal analisar quais as consequências que o atual Código de Processo Civil (2015) trouxe para a Perícia Contábil e para aqueles que podem se tornar peritos contadores em um futuro próximo. Para isso, realizouse uma pesquisa descritiva e levantamento, delineada como análise do sujeito coletivo e de abordagem qualitativa e quantitativa. Assim, a baixo estão expostas as consequências que o novo código de processo civil trouxe, na opinião dos peritos e estudantes.

Para os Peritos: 1) Os profissionais terão que estudar, se especializar e ter mais práticas; 2) Haverá limitações para a entrada na área; 3) Todos são a favor da educação continuada; 4) Estão ainda com dúvidas se as mudanças serão benéficas para a classe; 5) A maioria não concorda que as mudanças serão prejudiciais para os futuros perito; 6) Destacaram que é importante o perito demonstrar a especialização no objeto da perícia, trazendo benefícios para ele, como profissional e para a justiça, impedindo a entrada de leigos na área; 7) 100\% preferiram a atual condição imposta pelo NCPC, comprovar a especialização no objeto da perícia; 8) 100\% demonstraram que a especialização deverá ser em nível universitário.

Para os estudantes concluintes do curso de Ciências Contábeis: 1) Os pretensos peritos terão que estudar, se especializar, buscar experiências práticas para entrar no mercado; 2) A maioria achou que haverá limitantes para a entrada na área; 3) A maioria é a favor da educação continuada; 4) A maioria afirmou que as mudanças serão benéficas; 5) A metade concorda que as mudanças foram prejudiciais para os futuros peritos e a outra metade não concorda que as mudanças foram prejudicias, ficaram na dúvida, ou não tinham opinião. 6) A maioria acha positiva a exigência de o perito ser especializado no objeto da perícia; 7) A maioria acha as exigências do NCPC foram benéficas para todos; 8) A maioria defende que a melhor opção é que o perito seja especializado no objeto da perícia.

As contribuições desta pesquisa foram relacionadas com a análise dos artigos do novo CPC (2015) em comparação com os artigos do antigo CPC (1973), referente a perícia contábil. Também foi realizada a análise das respostas aos questionários aplicados aos peritos contadores que atuam na comarca de Cascavel - PR e aos alunos concluintes do Curso de Ciências Contábeis da UNIOESTE/Cascavel, que possibilitaram verificar as consequências das mudanças que o novo CPC trouxe para que atua ou pretende atuar na perícia contábil, visto que as mudanças afetaram ambas as partes.

Os resultados das análises dos questionários, por meio do método de análise do sujeito coletivo, possibilitou compreender a opinião dos peritos, que no geral estão satisfeitos com as novas alterações do CPC (2015), já que com essas exigências apenas profissionais especializados, com experiência, podem atuar na área de perícia. Por outro lado, para a maioria dos estudantes as mudanças são benéficas porque melhora a qualidade do trabalho do perito especialista, porém, exigir experiência é um fator que dificulta a entrada de novos profissionais na área de perícia.

As consequências das mudanças do CPC (2015) para os acadêmicos e Peritos foram confirmadas ao serem visualizadas o seu impacto no profissional contador perito, elas irão influenciar de forma negativa a atuação e o seu ingresso. Isso ficou perceptível com a análise dos artigos do antigo CPC (1973) e com o atual CPC (2015), que revelou as diversas exigências para atuar na área de perícia. Além das visões diferentes dos peritos e dos estudantes concluintes do curso de Ciências Contábeis, já que para os peritos as mudanças contribuem para o fortalecimento da profissão, mas para os estudantes essas mudanças dificultam a entrada de novos profissionais. 


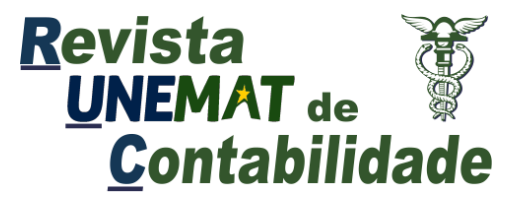

v. 8, n. 16,2019

O NCPC trouxe uma série de inovações e modificações que já vinham sendo reivindicadas a um bom tempo, visto que os avanços que ocorrem nas diversas áreas são intensos e constantes. Foram 42 anos (1973-2015), para a entrada em vigor de um CPC que contemplasse as necessidade atuais da população. As mudanças atingiram a área da informática, com os processos em formato digital, acesso via plataforma, identificação eletrônica (assinatura), e etc. A área de ensino, no sentido de especialização, visto que o acesso ao ensino superior está bem socializado. A área do direito, contemplando as novas demandas da sociedade civil e jurídica. E assim buscar a opinião de profissionais e de estudantes (concluintes) demonstra fazer sentido, pelo fato de que as mudanças afetam ambas as partes. De uma forma geral notou-se que os peritos visualizaram estas mudanças como algo benéfico para a profissão e isto é muito bom, pelo fato de que um profissional qualificado, especialista nas diversas áreas da perícia, que está sempre à busca da educação continuada fará com que se ofereça cada vez melhores serviçoes e se tenha a disposição bons profissionais. Por outro lado verificou-se que a maior preocupação que os estudantes (concluintes) tiveram, foi com as exigências para se conseguir ser um perito contábil. Estas mudanças levaram o CFC/CRCs a estar criando novos mecanismos de regulação para o perito contábil, como exame para perito, educação continuada, prestação de contas, reformulações de resoluções etc. Além das exigências dos próprios Tribunais de Justiça, de cada estado em relação aos seus respectivos cadastros. Desta forma verificou-se que as contribuições foram no sentido de explicitar a visão de cada uma das partes envolvidas na pesquisa, cada um visualizando aquilo que é melhor para si, sem deixar de destacar aqueles pontos que são benéficos para o todos, peritos, estudantes, justiça, população, etc.

Para trabalhos futuros na mesma linha de pesquisa, sugere-se aplicar o questionário ao maior número de peritos contábeis e estudantes de Ciências Contábeis, não apenas a nível municipal, como foi esse trabalho, mas com abrangência estadual ou até nacional.

ABSTRACT: In addition to having the skills of the profession, the expert must observe the legal legislation, with that contained in the new Code of Civil Procedure (CPC-2015), which is based on the role of assisting judges. The present study had the objective of analyzing the consequences that the requirements of the new Code of Civil Procedure have brought to Accounting Expert. It was used a descriptive research and survey, outlined as analysis of the discourse of the collective subject, with qualitative and quantitative approach. The study was applied to 10 accountants expert and 24 graduate students of the Accounting Sciences Course. Regarding the results found, it was found that the experts highlighted several points, emphasizing the consequences of the NCPC changes, the majority being favorable, with emphasis on positive points. For the graduating students of the Accounting Science course, they also highlighted several consequences of its application, but the emphasis was on the fact that the new law makes it difficult to enter as an expert and will require much more effort to maintain it. In general it was noted that the experts viewed these changes as beneficial to the profession, having qualified professionals, specialists. Students (graduating) focused on the requirements imposed by the NCPC. Thus, it was found that the contributions were to clarify the vision of each of the parties involved in the research, each visualizing what is best for you, while highlighting those points that are beneficial to all, experts, students, justice, population, etc.

KEYWORDS: Accounting Expert. New Code of Civil Procedure. Analysis of the Discourse of the Collective Subject.

\section{REFERÊNCIAS}

BRASIL. Lei $\mathrm{n}^{\circ} 5.869$ de 11 de janeiro de 1973. Institui o Código de Processo Civil. Vade 
Mecum Rideel. 12. ed. São Paulo: Rideel, 2011.

BRASIL. Lei $\mathrm{n}^{\circ} 13.105$ de 16 de março de 2015. Institui o Código de Processo Civil. Vade Mecum Saraiva. 12. ed. São Paulo: Saraiva, 2017.

CONSELHO FEDERAL DE CONTABILIDADE (CFC). Dispõe sobre as prerrogativas profissionais de que trata o artigo 25 do Decreto-lei $n^{\circ}$ 9.295, de 27 de maio de 1946. Resolução 560/83. Conselho Federal de Contabilidade, legislações. Disponível em: Acesso em 23/07/2016.

CONSELHO FEDERAL DE CONTABILIDADE. NBC PG 12 (R3) - Educação Profissional Continuada. Disponível em: www.crcpr.org.br/new/content/download/NBCPG12-R3.pdf Acesso em: 12/07/2017.

CONSELHO FEDERAL DE CONTABILIDADE. NBC TP 01 - Norma Técnica da Perícia Contábil. Disponível em: https://cfc.org.br/wp-content/uploads/2016/02/NBC_TP_01.pdf Acesso em: 12/07/2017.

CONSELHO FEDERAL DE CONTABILIDADE. NBC PP 01 - Norma Profissional do Perito. Disponível em: https://cfc.org.br/wp-content/uploads/2016/02/NBC_PP_01.pdf Acesso em: 13/07/2017.

CONSELHO REGIONAL DE CONTABILIDADE. Estatísticas de registros ativos no CRCPR em 31/08/2019. Disponível em: https://www.crcpr.org.br/new/content/camara/registro/quantosSomos.php. Acesso em: 31/08/2019.

DIAS, D. da S., PIMENTA, A. de A., BORBA, C. de L., SILVA, C. A. da, FAVERO, N. de C. J., Novo Código de Processo Civil: Um estudo sobre os impactos na Prática Pericia. Anais do Congresso de Administração, Sociedade e Inovação, Juiz de Fora, MG, 01 e 02/dez./2016. DONIZETTI, E. Novo código processo civil comparado. São Paulo: Atlas, 2015.

GARCIA, E., Uma breve discussão sobre a perícia judicial à luz do novo código de processo civil. Anais do I Congresso Brasileiro de Ciências Contábeis, Cascavel, PR, 21 a 25/Mai/2018.

HOOG, W. A. Z. Prova Pericial Contábil: teoria e prática. 14. ed. Curitiba, Juruá, 2017.LEFEVRE, F.; LEFEVRE, A. M. C. Pesquisa de Representação Social: um enfoque qualiquantitativo. 2. ed. Brasília: Liber Livro Editora, 2012.

MAGAlhãeS, A. D. F. et al Perícia Contábil. 6. ed. São Paulo: Atlas, 2009.

MELlO, P. C. de, A Perícia no Novo Código de Processo Civil. São Paulo: Trevisan Editora, 2016.

PINHATTI, A. K., SCHWEZ, N., Laudos Periciais Cíveis Contábeis sob o Enfoque do Novo Código do Processo Civil, ConTexto, Porto Alegre, v. 17, n. 37. P. 63-76, set./dez. 2017.

SILVA, P. M. da, MARTINS, M. A., Educação Continuada para a Atualização Profissional dos Peritos Contábeis: um enfoque sob o olhar dos peritos contadores da APEJUST $2^{\mathrm{a}}$ Região. Porto Alegre, 2018. TCC (Curso de Ciências Contábeis), Universidade Federal do Rio Grando do Sul.

SOUSA JUNIOR, A. B. de, SANTO, M. L. E., ARAÚJO, D. M., Aspectos técnicos da perícia contábil perante o Novo Código do Processo Civil, Scientiam Juris, v. 5, n.1, p. 6-16, 2017.

ZANNON, G., PELEIAS, I. R., WEFFORT, E. F. J., COUTO, M. B., A Percepção dos Juízes Paulistanos Acerca da Atuação do Perito Contador Assistente à Luz Código de Processo Civil, Revista Contabilidade Vista \& Revista, v. 29. N. 2, p. 122-149, mai./ago. 2018. 